\title{
21st-Century Skillset Perceptions of Students in an Information Technology Career Academy Compared to those at a Comprehensive School
}

\author{
Edward C. Fletcher Jr. \\ The Ohio State University \\ Amber D. Dumford \\ University of South Florida
}

\begin{abstract}
In this study, we compared the perspectives of students' 21 st-Century competencies (critical thinking and communication, applied learning, and intrapersonal and interpersonal skills) based on participating in an urban magnet information technology (IT) career academy compared to a traditional, comprehensive high school. We utilized propensity score matching to match academy and comprehensive high school learners on various demographic variables. The propensity score matching resulted in 299 matched pairs $(n=598)$. Using the matched groups, we ran linear regression models to investigate the relationship between school participation and students' perceptions of their $21^{\text {st }}$-Century skill attainment. We found that when compared with their comprehensive school peers, academy students believed their schools significantly contributed more to their abilities to apply knowledge from their coursework to a real-world context. We found no significant differences in critical thinking and communication skills as well as intrapersonal and interpersonal skills. Our findings indicate that the nature of the curriculum and instructional strategies within a career academy are beneficial. These strategies include the use of curriculum integration, workbased learning, and project-based learning to increase the meaningfulness and relevancy of content.
\end{abstract}

Keywords: career academy, college and career readiness, comprehensive school, magnet school, $21^{\text {st }}$ century skills

The goals for many secondary education institutions across the nation are ensuring that students leave school with the knowledge, skills and dispositions needed to be college and career ready. The career academy model emerged to meet those objectives and are found in over 7,000 high schools across the country (Bitterman et al., 2019; National Career Academy Coalition, 2019). They are in regional career centers, charter, magnet, and traditional comprehensive school settings. The goals of the career academy model are to indeed prepare students to be college and career ready. Career academies feature rigorous academic coursework embedded within various career themes (e.g., 
Business and Finance, Engineering, Health Sciences, Hospitality and Tourism, and Information Technology [IT]). The career academy model also focuses on providing a cohort of students within a small learning community with an array of work-based learning opportunities and college readiness initiatives (Fletcher et al., 2019).

The career academy model has been a focus for researchers with a body of research using experimental research designs (Kemple \& Scott-Clayton, 2004). However, there have been no research examining their effectiveness at equipping students with the knowledge, skills and dispositions as it relates to $21^{\text {st }}$-Century competencies; these competencies are critically important given our knowledge-based, technologically rich workforce environment. To that end, the purpose of this study was to examine how students perceive their $21^{\text {st }}$-Century skillsets (critical thinking and communication, applied learning, and intrapersonal and interpersonal skills) as a function of participating in an urban magnet IT career academy compared to students at a traditional comprehensive high school. The research questions undergirding this study were as follows:

1) Is there a significant difference in student perceptions of their critical thinking and communications skills gained in an urban magnet IT career academy compared to a traditional, comprehensive high school?

2) Is there a significant difference in student perceptions of their abilities to apply knowledge learned in school to a real-world setting for those in an urban magnet IT career academy compared to a traditional, comprehensive high school?

3) Is there a significant difference in student perceptions of interpersonal and intrapersonal skills gained in an urban magnet IT career academy compared to a traditional, comprehensive high school?

\section{Review of Literature}

High schools across the nation have emphasized the goals of ensuring their students are college and career ready by the time they graduate (Conley, 2010; Fletcher et al., 2018; Stone et al., 2012). However, it is clear that scholars and educational practitioners have yet to reach a consensus on the definitions of college and career readiness (Conley, 2010; Stone et al., 2012; Venezia et al., 2013). Some definitions of college and career readiness focus on ensuring that students take more core academic courses to assist in increasing tests scores and preparing them for participation in fouryear colleges and universities (Conley, 2010; Venezia et al., 2013). Yet, other definitions emphasize preparing high school students to enter postsecondary education as well as equipping them to compete in today's workforce - especially high demand, high skilled, and high wage careers (Fletcher et al., 2018; Lerman, 2013; Stone et al., 2012; Stringfield et al., 2017).

College and Career Readiness. In the context of this study, we used Stone and Lewis' (2012) definition of college and career readiness; college and career readiness within that context is defined as the need for students to acquire foundational academic knowledge as well as employability and technical skills needed to be successful. In terms of academic knowledge, students need the basic foundational knowledge in core subject areas (e.g., science, mathematics, and language arts) to equip them for success in a 
postsecondary education environment - without the need for remediation. Further, students need the occupational expression of academic knowledge which is their abilities to understand how core academic knowledge relates to real-world applications within the context of their career interests. Lerman (2013) argued, "Although many schools attempt to build some non-academic skills, measures of school performance primarily focus on increasing academic skills and not on enhancing other important skills" (p.6). Yet, school personnel need to be clear on their interpretations of college and career readiness for the purpose of setting their students up for success.

21st-Century Skills. Stone et al. (2012) also argued that it is not sufficient that students are academically prepared. Students also should acquire employability and technical skills within their careers of interest to be successful (Achieve, 2016). Employability skills are broad and include a range of competencies such as personal responsibility skills (e.g., responsibility, integrity, and self-management), critical thinking skills (e.g., creative and problem-solving), and technological skills (e.g., innovation and information management) (Partnership for 21 ${ }^{\text {st }}$-Century Skills, 2011; Secretary's Commission on Achieving Necessary Skills, 1991; Stone et al., 2012). Technical skills are based on the needed knowledge, skills, and dispositions for specific fields.

In 1991, a commission was developed - the Secretary's Commission on Achieving Necessary Skills (SCANS). Their purpose was to uncover the knowledge, skills, and abilities that employees need to be effective at their jobs. Based on a review of the literature, consultations with experts, and interviews with employees and their supervisors across 50 occupational areas, they developed several categories of competencies, including: basic skills (e.g., reading, writing, math, listening, speaking), personal qualities (e.g., responsibility, self-esteem, social, self-management, integrity, honesty), thinking skills (e.g., creative, decision-making, problem-solving, reasoning, and ability to learn), and workplace competencies (ability to allocate resources, interpersonal skills, and the ability to acquire and use information and work with technology). However, many educators do not address the non-academic or employability skills because they find it difficult to teach (Lerman, 2013). Nonetheless, career academy teachers use contextual teaching and learning for the development of their students' employability skills. Oftentimes, career academy teachers utilize instructional techniques, such as curriculum integration and work-based learning for their learners.

Contextual Teaching and Learning. Within the context of career academies, teachers often integrate their career-themed curricula with rigorous college preparatory content. To that end, the objective is for students to understand how their core academics may be applied to a real-world setting. Thus, career academy teachers are supposed to utilize contextual teaching and learning to make their content meaningful (Gordon et al., 2020; Hernandez-Gantes et al., 2003). The occupational context, then, becomes a source of relevant learning and applications involving authentic representations of the tasks that individuals perform within the world of work (Hernández-Gantes et al., 2003).

Curriculum Integration. Scholars have defined the concept of 'curriculum integration' in different ways - as a technique or process to align skills, themes, concepts, and topics across disciplines and between academic and career oriented curricula (Pierce \& Hernández-Gantes, 2015). Teachers who use curriculum integration strategies, connect multiple subject matter for the purpose of explaining theories, concepts, and ideas to enhance learning from one content area to another (Klein, 2006). Curriculum integration 
relies on an occupational theme such as Engineering or could emphasize connections within single subjects' areas such as arithmetic, algebra, geometry, or across two or more content areas, such as mathematics and CTE (Pierce et al., 2015). Curriculum integration may differ from least integrative (e.g., integration within a single course) to most integrative (e.g., cross-disciplinary integration) (Drake, 2007). Researchers in the Mathin-CTE experimental project found that curriculum integration using mathematical concepts in CTE courses resulted in significantly improved test scores for learners on two of three mathematical tests. Nevertheless, students' test results within the third examination were not significantly different from that of the control group (Stone et al., 2008; Stone \& Lewis, 2012).

Work-based Learning. School personnel implement work-based learning activities to ensure that their learners have experience in high-impact practices for the world of work (Gamboa et al., 2013). These activities include apprenticeships, guest speakers, job shadowing, mock interviews, paid or unpaid internships, and student-run enterprises (Cahill, 2016). Internships are the most common activity that students engage in with regard to work-based learning experiences. It also represents a signature feature of career academies. Kuh (2015) shared that high impact practices are when learners "invest substantial time and energy to educationally purposeful tasks, interact frequently with their teachers and peers, get feedback often, and apply what they are learning" (p. xi). To that end, work-based learning allows learners to use knowledge gained in the context of real-world settings, while exposing learners to, preparing them to go into, and ensuring they have the experience within their selected career pathway (Papadimitriou, 2014). Work-based learning experiences enable learners to gain employability and technical competencies to benefit them in both college and careers (Hernández-Gantes, 2016; Stone et al., 2012).

Lerman (2013) found that programs such as career academies enabled learners to gain higher levels of student engagement. This engagement was contributed to the workbased learning experiences students had - such as internships. These experiences led to a higher frequency of interaction with adults, higher feelings of productivity, and greater relevance of to core academic coursework. Lerman recommended that more research be conducted that examines in which ways learners can acquire needed employability skills (e.g., communication, teamwork, problem-solving) for success in postsecondary education environments and the workforce. Understanding that career academies emphasize student preparation for both college and careers as well as focus on curriculum integration work-based learning, for this research study, we examined the perspectives of students relating to their development of $21^{\text {st }}$-Century competencies (critical thinking and communication, applied learning, and intra- and interpersonal skills) based on participating in a career academy.

\section{Methods}

Research Design. We conducted this study using a correlational research design by collecting data with the high school survey of student engagement (Yazzie-Mintz, 2007). It is important to note that this study was a replication of Fletcher and Tan's (2021) study using a different data analytic procedure (propensity score matching) using two comparable schools within the same district. We also utilized data reduction 
techniques (exploratory factor analyses and confirmatory factor analyses) by developing scales from the items of the $21^{\text {st }}$-century skills questionnaire. For analytical techniques, we relied on descriptive statistics to present the demographic variables of our participants. We then used a propensity score matching technique to match academy learners with traditional comprehensive students on multiple demographic variables. Based on the matched groups, we ran independent samples t-tests for the mean differences and calculated Cohen's $d$ effect sizes for the 16 items on the questionnaire regarding obtaining $21^{\text {st }}$-Century competencies and the three scales that formed based on those questions. Lastly, we relied on general linear modeling to investigate the relationship between participation in a school (e.g., academy and comprehensive) and the obtainment of $21^{\text {st }}$-Century skills (Critical Thinking \& Communication Skills, Application of Knowledge, and Intrapersonal \& Interpersonal Skills), even when controlling for other variables.

School Context. Within our study, we had a NAF Academy of Information Technology and compared it to a traditional, comprehensive high school. Within the next section, we discuss the institutional variables, performance outcomes, and student demographics of each school. It is also important to note that we utilize pseudonyms in lieu of school names.

Cascade Academy. Cascade Academy of Information Technology is a distinguished (highest level of fidelity/implementation of NAF standards) wall-to-wall (all students participate in the academy' career theme) magnet NAF academy located in an urban setting in the Southeastern region of the country. Student admission to the academy is based on a lottery system. Within Cascade, students have the options of selecting from various IT career paths, including computer science, cybersecurity, gaming, multimedia design, and network systems. Every student at Cascade is issued a laptop for all four years of their schooling. As of the 2018-2019 academic year, Cascade had a student population of 685 . In terms of gender, they reported $75.6 \%$ of their students were male. For ethnic and racial background, Cascade had a 57\% White student population, 23\% Latinx students, 11\% African American/Black students, 7\%, Asian students $7 \%$, and $2 \%$ were Multi-Racial . Cascade also reported that $36 \%$ of their students qualified for free/reduced lunch prices, and $4 \%$ of were English Language Learners. During the academic year of 2017-2018, Cascade reported that $100 \%$ of their students graduated and $92 \%$ of their seniors were accepted into a postsecondary educational institution. In addition, Cascade reported that $21 \%$ of their students completed a paid, 120 hours or more internship.

Sampson High School. Sampson High School was a traditional, comprehensive school. It was situated within an urban setting in the Southeastern region of the country in the same school district as Cascade. There were 3,380 students at Sampson. In terms of ethnic and racial backgrounds, $38 \%$ of their students were White, $28 \%$ of their students were African American/Black, 20\% of students were Latinx, 11\% of their students were Asian, and 3\% of their students were Multiracial. Fifty-seven percent of students at Sampson qualified for free and/or reduced lunch. Their graduation rate for the 2017 to 2018 academic year was $89 \%$.

Sampling Procedure. We used purposive sampling in our selection of schools, an Academy of Information Technology and a traditional, comprehensive high school, for comparative reasons (Ary et al., 2006). Both schools were in the Southeastern part of the country 
and within the same school district. The combined student population of the two schools was 4,065 and 1,030 students responded ( $25 \%$ response rate) in our original sample.

We chose the Academy of Information Technology for multiple reasons, including its affiliation with NAF. NAF academies feature four components. The academy development and structure components emphasize small learning communities with students in cohorts, career-themed curricula, common teacher planning, careerthemed guidance, and continuous professional development of teachers. These academies also have integrated curriculum and instruction with career and academic instruction based on the career theme (e.g., Business and Finance, Engineering, Health Sciences, Hospitality and Tourism, Information Technology [IT]) as well as project-based learning activities for students involving coursework and work-based learning. Each academy is also expected to develop an advisory board with members that represent their local community to ensure academies are relevant and supported. Lastly, academies have work-based learning experiences for students that comprise career awareness and exploration activities in 9th (e.g., field trips) and 10th (e.g., job shadowing) grades, and hands-on experiences (e.g., industry certifications, paid internships) in 11th and 12th grades.

We selected the NAF model to ensure that the chosen academy followed standards of practice approved by a national organization recognized for such work. Therefore, we selected the site using the following criteria: (a) NAF Academy of Information Technology representing the highest levels of implementation (distinguished) using NAF's evaluation criteria; (b) a high rate of students who are ethnically and racially diverse and qualify for free and/or reduced lunch; and (c) a school within an urban context. We had 1,162 respondents comprised of 317 career academy students and 845 comprehensive learners. Of those, 1,030 completed all survey items (300 career academy and 730 comprehensive students). Participants were in 9th through 12 th grades.

\section{High School Survey of Student Engagement Instrument}

Instrument Validation. We established validity and reliability of the survey items. We first modified the original high school survey of student engagement questionnaire to align with the focus of this research project. We then sent the modified instrument to a panel of experts of six researchers and school administrators. They evaluated the latent variables of the questionnaire to assess each item's appropriateness. We then made modifications based on their recommendations. Then, we conducted cognitive interviews with six academy students to check for readability. We then conducted a pilot study with 30 student respondents. Finally, we ran exploratory and confirmatory factor analyses of each latent variable to evaluate construct validity (DeVellis, 2012).

Scale Construction. To assess the factor structures, we used exploratory and confirmatory factor analyses (EFA/CFA). We first randomly divided respondents into two groups. The first group provided data for the EFA, and the second one provided data for the CFA. We used polychoric correlations because it those data were ordinal in nature (Drasgow, 2006). We used principal component analysis with direct oblimin rotation (oblique). 
We identified eigenvalues of 1.0 or greater as well as factor loadings and crossloadings of 0.4 or more. The EFA included questions on the survey regarding how much

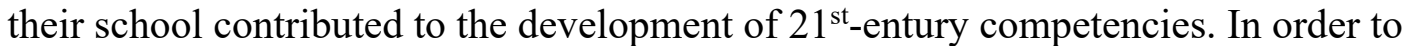
measure the fit our models, we examined five indices: GFI (goodness of fit index), CMIN/DF (chi-square divided by degrees of freedom), RMSEA (root mean square error of approximation), CFI (comparative fit index), and PCLOSE (p-value for test of close fit). The standard for good fit with CMIN/DF is a value of 5 or less, but since this statistic is sensitive to sample size and since it would most likely be inflated with the size of our sample, we also considered additional indices. Good model fit criteria considered for other indices were: CFI: .90 or higher; GFI: .85 or higher; RMSEA: .06 or lower; PCLOSE: .05 or higher (Hu \& Bentler, 1999). Standardized regression weights were used to investigate the strength of our factor loadings. These values range between 0 and 1 , with those closer to 1 being better. Values under .40 was unacceptably low (Kline, 2002). We assessed correlations for multicollinearity issues; these values of .80 or greater indicate multicollinearity and the possibility that factors are loading on multiple factors.

Based on our EFA results, it indicated that we had three distinct factors that explained $48 \%$ of the variance. The Kaiser-Meyer-Olkin statistic was .92, indicating a "marvelous" factorability of the item set (Kaiser, 1974). The Bartlett's test of sphericity was significant $(p<.001)$. We deleted two items that did not load well on any of the factors. We also removed one factor that did not make sense conceptually. Our results informed the CFA. We used the three factors from the EFA in the CFA. After developing the models, we used modification indices to examine if model fit could be enhanced by adding correlations between error terms of the individual survey items or the factor indicators. CFAs showed good model fit for all three scales, with all model fit indices being within the appropriate cut-off values (see Table 1).

\section{Table 1}

Confirmatory Factor Analysis: Model-fit Results

\begin{tabular}{ccccc}
\hline CMIN/DF & GFI & CFI & RMSEA & PCLOSE \\
\hline 2.601 & .965 & .976 & .054 & .259
\end{tabular}

Note: Strong model fit is reflected by GFI greater than .85 , CFI greater than .90 , RMSEA less than .06 , and PCLOSE greater than .05. 
As expected, all three engagement scales were correlated with one another (.289 for Critical Thinking \& Communication Skills and Application of Knowledge; 332 for Critical Thinking \& Communication Skills and Intra- \& Interpersonal Skills; and .485 for Application of Knowledge and Intrapersonal \& Interpersonal Skills). This demonstrated that the factors are related, but do not pose multicollinearity concerns. We found strong standardized regression weights for all factors across all four groups; they ranged from approximately .5 to .8. Our overall fit indices, factor correlations, and regression weights provided adequate construct validity evidence for all the three scales. See Table 2 for details.

Table 2

Confirmatory Factor Analysis Results

\begin{tabular}{lcc}
\hline & $\begin{array}{c}\text { Standardized } \\
\text { Regression } \\
\text { Weights }\end{array}$ & $\begin{array}{c}\text { Internal } \\
\text { Consistency } \\
(\alpha)\end{array}$ \\
\hline Critical Thinking \& Communication Skills (6 items) & .816 & $\mathbf{. 8 4}$ \\
Thinking critically (reasoning, asking "Why?") & .771 & \\
Developing creative ideas and solutions & .720 \\
Reading and understanding challenging materials & .686 & \\
Speaking effectively & .676 & \\
Writing effectively & .567 & \\
Using technology to gather and communicate information & .716 & \\
Application of Knowledge (4 items) & .713 & \\
Acquiring skills for a job after completing high school & .703 & \\
Applying school-based knowledge to everyday life & .677 & \\
Understanding the connection between what you learn in school & & \\
$\quad$ and its importance after high school & .81 \\
Developing career goals & .833 \\
Intrapersonal \& Interpersonal Skills (3 items) & .751 \\
Understanding yourself & .713 \\
Developing personal beliefs and values & & \\
Treating people with respect & & \\
\hline
\end{tabular}

Survey Dimensions. We included 16 questions from the larger 140-item questionnaire. The items asked, "How much has your experience at this school contributed to your development in the following areas?" and we utilized a 4-point Likert-type scale, where 1 = "Not at all," 2 = "Very little," 3 = "Some," and 4 = "Very much." The questions included the following: "acquiring skills for a job after completing high school"; "writing effectively"; "speaking effectively"; "thinking critically (reasoning, asking 'Why?')"; "developing creative ideas and solutions"; "reading and understanding challenging materials"; "using technology to gather and communicate information"; "working well with others to complete a task"; "learning independently"; "applying school-based knowledge to everyday life"; "learning what life is like for other people in your community outside of school"; "developing career goals"; "understanding 
the connection between what you learn in school and its importance after high school"; "understanding yourself"; "treating people with respect"; and "developing personal beliefs and values." After we identified the items for each scale, we averaged the scores on the items within each scale.

Critical Thinking \& Communication Skills. The critical thinking and communication skills construct was comprised of six items. This scale assessed students' perceptions of how much their schools contributed to their abilities to think critically, develop creative ideas and solutions, read and understand challenging materials, speak and write effectively, and use technology to gather and communicate information. The internal consistency was strong $(\alpha=.84)$.

Application of Knowledge. The application of knowledge construct was comprised of four items. This scale examined learners' perceptions of how their schools influenced their abilities to align their learning in class to real-world and future situations. The items included: the connection between learning in school and its importance post high school, developing career goals, matching learning in school to their everyday lives, and obtaining skills for a job post high school. The internal consistency was strong $(\alpha=$ $.82)$.

Intrapersonal \& Interpersonal Skills. The intrapersonal and interpersonal skills construct was comprised of three items. This scale assessed the students' perceptions of how much their schools contributed to their abilities to understand themselves and relate to each other. The specific items included developing personal beliefs and values, treating people with respect, and understanding themselves. The internal consistency was strong $(\alpha=.81)$.

\section{Data Analysis}

To reduce initial differences between samples, we utilized propensity score matching to match NAF academy students with their comprehensive high school counterparts (Luellen et al., 2005; Rubin, 1997; Rubin et al., 2000). Propensity score matching assisted in the reduction of bias due to other confounding variables that might explain the dependent variable. It also helps to reduce bias from the inability to utilize randomization. Thus, we tried to control for the differences in NAF and their comprehensive student counterparts by controlling for differences in ethnic and racial background (American Indian/Alaska Native; Asian or Asian American; Native Hawaiian or Other Pacific Islander; African American or Black; Hispanic, Latinx, or Spanish origin; White; Other; Prefer not to respond; and Multiracial), gender (male/female/nonconforming), socio-economic status (measured by free/reduced lunch status), grade in school ( $9^{\text {th }}$ through $\left.12^{\text {th }}\right)$, and language primarily spoken at home (English, Spanish, or other). We used propensity scores for each student participant based on the aforementioned demographic variables, and we then used the nearest neighbor matching function (without replacement) to match each participant or non-participant base on their propensity scores.

Based on the pairs of the propensity score matching, we compared the group differences using t-tests for all of the sixteen $21^{\text {st }}$-Century competency items and the three scales (Critical Thinking \& Communication Skills, Application of Knowledge, and Intrapersonal \& Interpersonal Skills). Given that statistical significance is sensitive to the 
size of the sample, we used Cohen's $d$ effect sizes (mean difference/pooled standard deviation) (Cohen, 1988, 1992). Cohen (1988) categorized the different effect sizes as "small, $d=.2, "$ "medium, $d=.5$," and "large, $d=.8$," but noted that "there is a certain risk inherent in offering conventional operational definitions for those terms used in power analysis in as diverse a field of inquiry as behavioral science" (p. 25) and encouraged researchers to use their own unique discipline's standards when interpreting their effect sizes. Researchers have noted that these cut-offs may be ambitious (Gonyea \& Sarraf, 2009; Mayhew et al., 2016).

Student Demographics of the Two Schools. For the initial sample of students, before the propensity score matching, we found statistically significant differences in all of the demographic variables in our study (gender, race/ethnicity, grade, and free/reduced lunch status). Female respondents were the majority in the comprehensive school (58.3\%), nearly three-quarters of the career academy respondents (71.9\%) were male. Further, comprehensive school respondents were more ethnically and racially diverse (72.4\%) compared to their academy learners (55.9\%). While a table with the complete details on the initial sample demographics are not included here, they can be seen in an article using data from the same larger study (see Table 4 in Fletcher et al., 2020). In contrast, when comparing the two schools using the matched pairs created through the propensity score matching, no statistically significant differences were found among the respondents in the schools (see Table 5 in Fletcher et al., 2020).

\section{Results}

Mean Comparisons. Of the 16 skills in this study, we found that six of the skills were statistically significant when comparing academy students to their comprehensive school peers. For four of the six skills, academy learners, when compared to their comprehensive school counterparts, contributed more of the development of their skillset to the experiences at their high school. The four skills included, job skills needed after graduating from highs school $(M=3.33$ and $M=2.93$, respectively; $\mathrm{p}<.001)$, abilities to develop creative ideas and solutions $(M=3.21$ and $M=3.09$, respectively; $\mathrm{p}<.05)$, use of technology to gather and communicate information $(M=3.21$ and $M=3.09$, respectively; $\mathrm{p}<.001)$, and development of career goals $(M=3.32$ and $M=3.11$, respectively; $\mathrm{p}<.001)$. Conversely, for both their ability to write effectively $(M=3.10$ and $M=3.22$, respectively; $\mathrm{p}<.05$ ) and understanding what life is like for other people in their community outside of school $(M=2.55$ and $M=2.73$, respectively; $\mathrm{p}<.05)$, academy students contributed less of their growth to their school compared to their comprehensive school peer. Finally, the effect sizes of the differences in four of the six cases is small and perhaps trivial differences: abilities to develop creative ideas and solutions $(d=.16)$, development of career goals $(d=.26)$, ability to write effectively $(d=$ $-.16)$, and understanding what life is like for other people in your community outside of school $(d=-.19)$. In contrast, the effect sizes for the final two previously discussed skills were nontrivial differences. They would be considered near medium, for job skills needed after graduating from highs school $(d=.48)$, and medium to large for use of technology to gather and communicate information $(d=.64)$ - even by Cohen's conservative standards (Cohen, 1998). 
When looking at the scales, one (Application of Knowledge) of the three scales had a statistically significant difference $(\mathrm{p}<.001)$. Academy learners, compared to comprehensive school peers, perceived that their school contributed to their abilities to apply knowledge $(d=.30)$ more. Additionally, this difference is nontrivial to medium in size (Cohen, 1998). For more specifics, see Table 3 below.

\section{Table 3}

Summary of T-tests and Effect Sizes Comparing Academy Students with Comprehensive Students on $21^{\text {st }}$-Century Skills Items \& Scales

\begin{tabular}{|c|c|c|c|c|c|}
\hline & $\begin{array}{l}\text { Academy } \\
(\mathrm{n}=299)\end{array}$ & $\begin{array}{l}\text { Comp. } \\
(\mathrm{n}=299)\end{array}$ & $\begin{array}{c}\text { Mean } \\
\text { Difference }\end{array}$ & $t$ & $\begin{array}{c}\text { Effect } \\
\text { Size } \\
D\end{array}$ \\
\hline $\begin{array}{l}\text { Critical Thinking \& Communication Skills } \\
\text { (Scale): }\end{array}$ & 3.24 & 3.16 & 0.08 & 1.67 & 0.14 \\
\hline Writing effectively & 3.10 & 3.22 & -0.13 & $1.95^{*}$ & -0.16 \\
\hline Speaking effectively & 3.01 & 3.07 & -0.06 & .92 & -0.08 \\
\hline Thinking critically & 3.25 & 3.22 & 0.03 & .46 & 0.04 \\
\hline $\begin{array}{l}\text { Developing creative ideas and } \\
\text { Solutions }\end{array}$ & 3.21 & 3.09 & 0.12 & $1.92 *$ & 0.16 \\
\hline $\begin{array}{l}\text { Reading and understanding } \\
\text { challenging materials }\end{array}$ & 3.23 & 3.18 & 0.04 & .70 & 0.06 \\
\hline $\begin{array}{l}\text { Using technology to gather and } \\
\text { communicate information }\end{array}$ & 3.61 & 3.14 & 0.47 & $7.86^{* * *}$ & 0.64 \\
\hline Application of Knowledge (Scale): & 3.15 & 2.94 & 0.21 & $3.66 * * *$ & 0.30 \\
\hline $\begin{array}{l}\text { Acquiring skills for a job after } \\
\text { completing high school }\end{array}$ & 3.33 & 2.92 & 0.41 & $5.85^{* * *}$ & 0.48 \\
\hline $\begin{array}{l}\text { Applying school-based knowledge to } \\
\text { everyday life }\end{array}$ & 2.95 & 2.84 & 0.11 & 1.46 & 0.12 \\
\hline Developing career goals & 3.32 & 3.11 & 0.22 & $3.23 * * *$ & 0.26 \\
\hline $\begin{array}{l}\text { Understanding the connection } \\
\text { between what you learn in school } \\
\text { and its importance after HS }\end{array}$ & 3.00 & 2.91 & 0.09 & 1.19 & 0.10 \\
\hline Intra- \& Interpersonal Skills (Scale) & 3.02 & 3.01 & 0.01 & 0.09 & 0.01 \\
\hline Understanding yourself & 2.82 & 2.80 & 0.02 & 0.21 & 0.02 \\
\hline Treating people with respect & 3.24 & 3.26 & -0.02 & 0.35 & -0.03 \\
\hline $\begin{array}{l}\text { Developing personal beliefs and } \\
\text { Values }\end{array}$ & 2.99 & 2.97 & 0.02 & 0.31 & 0.02 \\
\hline \multicolumn{6}{|l|}{ Items not in a Scale: } \\
\hline $\begin{array}{l}\text { Working well with others to complete } \\
\text { a task }\end{array}$ & 3.16 & 3.10 & 0.06 & .96 & 0.08 \\
\hline
\end{tabular}




\begin{tabular}{llllll} 
Learning independently & 3.25 & 3.30 & -0.05 & 0.84 & -0.07 \\
$\begin{array}{l}\text { Learning what life is like for other } \\
\text { people in your community outside } \\
\text { of school }\end{array}$ & 2.55 & 2.73 & -0.18 & $2.27^{*}$ & -0.19 \\
\hline$* p<.05 ; * * p<.01 ; * * p<.001$ & & & & &
\end{tabular}

Regression Models. The results from the OLS regressions mirrored those of the previously discussed t-tests. The models indicated that students that participate in an academy might perceive that their school contributed more to their development of one of the three scales around $21^{\text {st }}$-Century skills when compared to comprehensive school peers, after controlling for learners' gender, ethnic and racial backgrounds, free/reduced lunch, grade in school, and primary language spoken at home. Specifically, those students attending a NAF academy believed their school influenced their ability to apply their knowledge $(\beta=.15 ; p<.001)$ more.

Year in school $\left(10^{\text {th }}, 11^{\text {th }}\right.$, and $12^{\text {th }}$ in comparison to $\left.9^{\text {th }}\right)$ was fairly consistent in its influence on all of the $21^{\text {st }}$-Century skills scales. We found statistically significant differences between students in $12^{\text {th }}$ grade and $9^{\text {th }}$ for all three of the skill sets and $11^{\text {th }}$ and $9^{\text {th }}$ for two of the skills (Critical Thinking \& Communication Skills and Intrapersonal \& Interpersonal skills). Gender nonconforming students indicated that their school influenced their Critical Thinking and Communication Skills less than their male peers. Only one statistically significant finding was revealed for ethnicity/race. African American/Black students perceived that their school influenced their abilities to apply knowledge more when compared to their White peers. Learners who qualified qualify for free and/or reduced-priced lunch reported slightly more intrapersonal and interpersonal skills compared with their peers that do not qualify. Table 4 shows of the findings.

Table 4

OLS Regression Models for Three $21^{\text {st }}$-Century Skills Scales

\begin{tabular}{|c|c|c|c|c|c|c|}
\hline & $\begin{array}{l}\text { Critical Thinking } \\
\text { \& Communication }\end{array}$ & & $\begin{array}{c}\text { Application } \\
\text { of } \\
\text { Knowledge }\end{array}$ & & $\begin{array}{l}\text { Intrapersonal \& } \\
\text { Interpersonal } \\
\text { Skills }\end{array}$ & \\
\hline & $\beta$ & $p$ & $\beta$ & $p$ & $\beta$ & $p$ \\
\hline \multicolumn{7}{|l|}{$\underline{\text { School }}^{1}$} \\
\hline \multirow{2}{*}{\multicolumn{7}{|c|}{ Gender ${ }^{2}$}} \\
\hline & & & & & & \\
\hline Female & -.03 & & -.06 & & -.02 & \\
\hline Nonconforming & -.09 & $*$ & -.02 & & -.05 & \\
\hline \multicolumn{7}{|l|}{ Grade $^{3}$} \\
\hline $10^{\text {th }}$ & .08 & & .06 & & .06 & \\
\hline $11^{\text {th }}$ & .17 & $* * *$ & .07 & & .08 & * \\
\hline $12^{\text {th }}$ & .16 & $* * *$ & .09 & $*$ & .12 & ** \\
\hline \multicolumn{7}{|l|}{ Ethnicity/Race ${ }^{4}$} \\
\hline AmerInd/Alaskan & .01 & & .00 & & .01 & \\
\hline Asian & .04 & & .07 & & .05 & \\
\hline Black & .08 & & .13 & $* *$ & .06 & \\
\hline Hawaiian/Pacific & -.01 & & .03 & & -.01 & \\
\hline Latinx & -.01 & & .09 & & .08 & \\
\hline
\end{tabular}




\begin{tabular}{|c|c|c|c|c|}
\hline Multi-Racial & -.09 & .01 & -.01 & \\
\hline Other & .02 & -.04 & .01 & \\
\hline Prefer Not Resp. & .03 & -.02 & -.01 & \\
\hline \multicolumn{5}{|c|}{ Language Spoken At Home ${ }^{5}$} \\
\hline Spanish & .07 & -.01 & .02 & \\
\hline Other & -.05 & -.02 & -.06 & \\
\hline \multicolumn{5}{|c|}{ Free/Reduced Price Lunch ${ }^{6}$} \\
\hline Yes & .07 & .01 & .11 & * \\
\hline Don't know & .00 & -.06 & -.02 & \\
\hline Prefer Not Resp. & .00 & -.04 & -.03 & \\
\hline$R^{2}$ & $.079 * * *$ & $.068 * *$ & $.059 * *$ & \\
\hline \multicolumn{5}{|c|}{${ }^{1}$ Reference group: Comprehensive } \\
\hline \multicolumn{5}{|c|}{${ }^{2}$ Reference group: Male } \\
\hline \multicolumn{5}{|c|}{${ }^{3}$ Reference group: 9 th } \\
\hline \multicolumn{5}{|c|}{${ }^{4}$ Reference group: White } \\
\hline \multicolumn{5}{|c|}{${ }^{5}$ Reference group: English } \\
\hline \multicolumn{5}{|c|}{${ }^{6}$ Reference group: No } \\
\hline$* p<.05 ; * * p<.01$ & & & & \\
\hline
\end{tabular}

\section{Discussion}

Although career academies are likely the most popular and long-lasting comprehensive high school reform initiatives aimed at preparing students for college and career readiness, there are no studies demonstrating how students view their $21^{\text {st }}$-Century competency development for their participation in our modern and technologically based workforce (Bitterman et al., 2013; Lanford et al., 2019; National Career Academy Coalition, 2019). In this study, we assessed how learners perceived of their $21^{\text {st }}$-Century competencies (critical thinking and communication, applied learning, and intrapersonal and interpersonal skills) based on their participation in an urban magnet IT career academy compared to students at a traditional comprehensive high school. We found that students in the technology-rich, applied academic setting of an IT career academy were significantly more likely to have higher perceptions of their abilities to apply their knowledge to real-world contexts.

Findings in this study indicated no significant differences in learners' perceptions of their skillsets regarding communication and critical thinking skills compared to those at a traditional, comprehensive high school. However, within the communication and critical thinking skill construct, we found significant differences with certain individual items. Academy students perceived their level of competence with developing creative ideas and solutions as well as using technology to gather and communicate information to be significantly higher than those in a traditional, comprehensive school. Students' heightened perceptions of their abilities to develop creative ideas and solutions are likely due to the problem- and project-based nature of curricula in the career academy. Career academy teachers structure their curricula using problem-, project-, and team-based learning to enhance students' problem-solving skills (Fletcher et al., 2012; Fletcher et al., 2017). At Cascade Academy, students oftentimes work in teams to solve real-world problems related to gaming and cybersecurity. These strategies likely led to a higherlevel competency of students in the realm of developing creative ideas and solutions to 
real-world problems. Further, the work-based learning activities, particularly with internships, help students learn to solve problems within the context of a workplace environment.

It is not surprising that academy learners were significantly more likely to use technology to collect and disseminate information. Cascade had multiple IT paths: computer science, gaming, multimedia design, cybersecurity, and network systems. The nature of the content learned in the academy likely prepared them to work within our technologically driven, knowledge-based economy as technology has become ubiquitous in work and postsecondary education programs.

However, comprehensive students were significantly more likely to believe that their school prepared them to write effectively. This is a challenge that needs to be addressed in high school career academies. Writing effectively is a necessary skill related to communication both in the workplace environment and for advanced postsecondary education. We recommend that teachers in career academies integrate more writing within the contexts of IT curricula. Thus, we believe students should not only be required to verbally present material, but also write reports for their class projects. It is equally important for teachers to provide substantive feedback on their written work to ensure students understand proper writing conventions

Findings also suggested a statistically significant difference in academy and comprehensive school students related to applying knowledge to real-world settings. Academy students believed that they had significantly higher competencies related to applying their knowledge in the classroom to the real-world. While not surprising, this finding demonstrates that this career academy is adhering to the academy model by integrating career-themed content with college preparatory curricula to ensure students are learning core academic subjects in an applied context. School personnel in career academies utilize contextual teaching and learning to make learning more meaningful for students by emphasizing alignment to real-life contexts (Gordon et al., 2020; HernandezGantes et al., 2003). It also is likely that career academy learners benefit from the practice of curriculum integration.

Academy students also believed they had higher abilities to align coursework to real-world settings based on their participation in various work-based learning experiences (Fletcher et al., 2019; Lerman, 2013). This ensures that students are able to apply their learning to real-world settings, while building exposure to, preparation for, and experience in their chosen career pathways (Lerman, 2013; Papadimitriou, 2014). Work-based learning activities help learners obtain both the employability and technical skills needed to for college and career readiness (Hernández-Gantes, 2016; Stone et al., 2012). Thus, participation in work-based learning were likely what led academy learners to have significantly higher abilities of their attainment of skills for a job post high school as well as developing career goals.

Another noteworthy issue to address is that comprehensive learners were significantly more likely to possess higher abilities to learn what life is like for others in their own communities. This signals the need for career academy administrators and teachers to ensure academy students have the experience of working in their community. Therefore, we recommend academies set a policy to require academy students to participate in a certain number of service-learning hours as well as provide the opportunities to reflect on their experiences and what they learned with engaging with 
individuals in their community. Further, students in career academies should have capstone projects to present (both written and verbally) and reflect on their experiences and associated learning.

It is important to note that readers should use caution in attempting to generalize the findings in our study to other school settings and contexts given that we had only two schools in this study and these schools included a small magnet academy and large comprehensive school. We also further unable to understand how each school characteristic (e.g., magnet, career academy, small size, work-based learning) influenced students' perceptions of their $21^{\text {st }}$-Century competencies. We also acknowledge that the list of $21^{\text {st }}$-Century competencies identified in this study is not comprehensive; hence, there are various $21^{\text {st }}$-Century skill constructs that were not used in our study. Also, the measures in our project relied on self-reported data. Thus, the extent to which our findings are generalizable rests on the degree that schools have similar characteristics (e.g., magnet schools that use a lottery system for student admission and comprehensive schools with large student populations).

\section{References}

Achieve. (2016). The college and career readiness of high school graduates. Washington, DC: Author.

Ary, D., Jacobs, L., Razavieh, A., \& Sorensen, C. (2006). Introduction to research in education (7th ed.). Thomson Wadsworth.

Bitterman, A., Gray, L., \& Goldring, R. (2013). Characteristics of public and private elementary and secondary schools in the United States: Results from the 2011-2012 schools and staffing survey (NCES 2013-311). U.S. Department of Education. Washington, DC: National Center for Education Statistics.

Cahill, C. (2016). Making work-based learning work. Retrieved from the Jobs for the Future website http://www.jff.org/

Castellano, M., Sundell, K., Overman, L. T., \& Aliaga, O. A. (2012). Do career and technical education programs of study improve student achievement? Preliminary analyses from a rigorous longitudinal study. International Journal of Educational Reform, 21(2), 98-118.

Cohen, J. (1988). Statistical power analysis for the behavioral sciences (2nd ed.). Lawrence Erlbaum Associates.

Cohen, J. (1992). A power primer. Psychological Bulletin, 112(1), 155-159. doi: 10.1037//00332909.112.1.155

Conley, D. (2010). College and career ready: Helping all students succeed beyond high school. Jossey-Bass.

DeVellis, R. (2012). Scale development: Theory and applications (3rd ed.). Sage.

Drake, S. (2007). Creating standards-based integrated curriculum (2nd ed.). Corwin Press.

Drasgow, F. (2006). Polychoric and polyserial correlations. Encyclopedia of statistical sciences. http://onlinelibrary.wiley.com/book/10.1002/0471667196

Fletcher, E.C., \& Cox, E. (2012). Exploring the meaning African American students ascribe to their participation in high school career academies and the challenges they experience. The High School Journal, 96(1), 4-19. doi:10.1353/hsj.2012.0017

Fletcher, E.C., Dumford, A., Hernandez-Gantes, V.M., \& Minar, N. (2020). Examining the engagement of career academy and comprehensive high school students in the United States. Journal of Educational Research, 113(4), 247-261. doi:10.1080/00220671.2020.1787314. 
Fletcher, E.C., \& Tan, T.X. (2021). Examining the 21st century skillset perceptions of academy and comprehensive school students. Thinking Skills and Creativity, 40, 1-12. doi:10.1016/j.tsc.2021.100817.

Fletcher, E.C., \& Tyson, W. (2017). Bridging technical skills gaps between high school students and local employers. Journal of Research in Technical Careers, 1(1), 20-31. doi:10.9741/2578-2118.1001

Fletcher, E.C., Warren, N., \& Hernandez-Gantes, V.M. (2018). Preparing high school students for a changing world: College, career, and future ready learners. Career and Technical Education Research, 43(1), 77-98. doi:10.5328/cter43.1.77

Fletcher, E.C., Warren, N.Q., \& Hernandez-Gantes, V.M. (2019). The high school academy as a laboratory of equity, inclusion, and safety. Computer Science Education, 29(4), 382-406. doi:10.1080/08993408.2019.

Gamboa, V., Paixão, M. P., \& Neves de Jesus, S. (2013). Internship quality predicts career exploration of high school students. Journal of Vocational Behavior, 83(1), 78-87. doi:10.1016/j.jvb.2013.02.009

Gonyea, R., \& Sarraf, S. (2009, June). Contextualizing NSSE effect sizes: Empirical analysis and interpretation of benchmark comparisons. Paper presented at the Annual Forum of the Association for Institutional Research, Atlanta, GA.

Gordon, H., \& Schultz, D. (2020). The history and growth of career and technical education in America (5th ed.). Waveland Press.

Hernández-Gantes, V.M. (2016). College and career readiness for all: The role of career and technical education in the US. In Wyse, D., Hayward, L., \& Pandya, J. (Eds.), SAGE Handbook of Curriculum, Pedagogy and Assessment. Vol. 2 (674-689). SAGE.

Hernández-Gantes, V.M., \& Brendefur, J. (2003). Developing authentic, integrated, standardsbased mathematics curriculum: [More than just] an interdisciplinary collaborative approach. Journal of Vocational Education Research, 28(3), 259-284.

Hu, L. T., \& Bentler, P. M. (1999). Cutoff criteria for fit indices in covariance structure analysis: Conventional versus new alternatives. Structural Equation Modeling, 6(1), 1-55. doi: $10.1080 / 10705519909540118$

Kaiser, H.F. (1974). An index of factorial simplicity. Psychometrika, 39(1), 31-36. doi: 10.1007/BF02291575

Kemple, J., \& Scott-Clayton, J. (2004). Career academies: Impacts on labor market outcomes and educational attainment. Manpower Demonstration Research Corporation.

Klein, J. T. (2006). Platform for a shared discourse of interdisciplinary education. Journal of Social Science Education, 6(2), 10-18. http://www.jsse.org

Kline, P. (2002). An easy guide to factor analysis. Routledge.

Kuh, G. D. (2015). Foreword. In S. J. Quaye \& S. R. Harper (Eds.), Student engagement in higher education (pp. ix-xiii). Routledge

Lanford, M., \& Maruco, T. (2019). When job training is not enough: The cultivation of social capital in career academies. American Educational Research Journal, 55(3), 617-648. doi: $10.3102 / 0002831217746107$

Lerman, R. (2013). Are employability skills learned in U.S. youth education and training programs? IZA Journal of Labor Policy, 2(6). doi: https://doi.org/10.1186/2193-9004-2-6

Luellen, J.K., Shadish, W.R., \& Clark, M.H. (2005) Propensity scores: An introduction and experimental test. Evaluation Review, 29(6), 530 -58. doi: 10.1177/0193841X05275596

Mayhew, M. J., Rockenbach, A. N., Bowman, N. A., Wolniak, G. C., Seifert, T. A. D., Pascarella, E. T., \& Terenzini, P. T. (2016). How college affects students: 21 st century evidence that higher education works. https://ebookcentral.proquest.com

National Career Academy Coalition. (2019). Career academies change lives every day. https://www.ncacinc.com/nsop/academies 
Papadimitriou, M. (2014). High school students' perceptions of their internship experiences and related impact on career choices and changes. Online Journal for Workforce Education \& Development, 7(1), 1-27.

Partnership for $21^{\text {st }}$ Century Skills (2011). A framework for $21^{\text {st }}$ century learning. Retrieved from http:://www.p21.org

Pierce, K., \& Hernández-Gantes, V.M. (2015). Do mathematics and reading competencies integrated into career and technical education courses improve high school student scores? Career and Technical Education Research, 39(3), 213-229. doi: $10.5328 /$ cter39.3.213

Rubin, D. (1997) Estimating causal effects from large data sets using propensity scores. Annals of Internal Medicine, 127(8), 757-763.

Rubin, D., \& Thomas, N. (2000) Combining propensity score matching with additional adjustments for prognostic covariates. Journal of the American Statistical Association, 95(450), 573-585. doi: 10.2307/2669400

Secretary's Commission on Achieving Necessary Skills (SCANS) (1991). What work requires of schools: A SCANS report for America 2000. U.S. Department of Labor website: http://wdr.doleta.gov

Stone, J. R. III, Alfeld, C., \& Pearson, D. (2008). Rigor and relevance: Testing a model of enhanced math learning in career and technical education. American Educational Research Journal, 45(3), 767-795. doi: 10.3102/0002831208317460

Stone, J.R. III, \& Lewis, M.V. (2012). College and career ready in the 21st century: Making high school matter. Teachers College Press.

Stringfield, S., \& Stone, J. R. III. (2017). The labor market imperative for CTE: Changes and challenges for the $21^{\text {st }}$ century. Peabody Journal of Education, 92(2), 166-179. doi: 10.1080/0161956X.2017.1302207

Venezia, A., \& Jaeger, L. (2013). Transitions from high school to college. The Future of Children, 23(1), 117-136. doi: 10.1353/foc.2013.0004

Yazzie-Mintz, E. (2007). Voices of students on engagement: A report on the 2006 High School Survey of Student Engagement. Bloomington: Center for Evaluation \& Education Policy, Indiana University.

\section{ACKNOWLEDGEMENT}

This research was supported by grants from the National Science Foundation's ITEST program (Award \# 1614707 \& 2016580). 